\title{
舌下面正中に発生した軟骨性分離腫
}

\author{
安井康順・木村哲雄・太田之博 \section{of the inferior surface of the tongue} \\ Cartilaginous choristoma occurring at the midline
}

\author{
YASUI Yasunobu $\cdot$ KIMURA Tetsuo $\cdot$ OHTA Yukihiro
}

\begin{abstract}
We report a case of cartilaginous choristoma of the tongue with a review of the literature. A 76-year old woman had been aware of a soft tumor present at the midline of the inferior surface of the tongue for several years. At presentation, the tumor was approximately $8 \mathrm{~mm}$ in diameter and situated in the middle of the inferior surface of the tongue. The tumor was excised under local anesthesia. Histological examination revealed that the tumor had cartilaginous characteristics. The histological diagnosis was cartilaginous choristoma of the tongue. To our knowledge, this tumor has not yet been reported previously in this region. The etiology of this tumor remains unclear. The most plausible theory is that the tumor originates from traces of ectopic embryonic tissue or mesenchymal metaplasia.
\end{abstract}

Key words: cartilaginous choristoma（軟骨性分離腫), tongue（舌), review of literature（文献的検索）

緒

舌の軟骨性分離腫は舌の発生途中に軟骨組織が迷入し, 生存增殖して腫瘤状となる比較的まれな良性腫瘍でこれま で 10 例が報告されているに過ぎずその発生部位は半数が 舌背正中であり，舌下面正中の報告はみられない，今回 我々は同部に発生した軟骨性分離腫を経験したので報告す る.

\section{症例}

患 者：76歳, 女性.

初 診: 平成 16 年 10 月

主 訴: 舌の違和感.

既往歴：本院乳腺外科にて左乳房切除術（平成 15 年 9

月—）後，本院形成外科にて再建・植皮術を受け経過 観察中.

家族歴：特記事項なし.

現病歴：数年前から舌下正中に弾性軟の腫瘤を認めるも 痛みがないため放置していた，最近同腫瘤が次第に大きく なってきたため, 精查を希望し, 乳房再建を受けた形成外 科主治医から紹介され，平成 16 年 10 月—, 本科を受診

大阪警察病院菌科口腔外科

(主任：木村哲雄部長)

Osaka Police Hospital, Department of Dentistry and Oral

Surgery (Chief: KIMURA Tetsuo)

受付日：2005年 9 月 5 日

採択日：2006 年 1 月 31 日
した.

現 症 :

全身所見；体格中等度.

口腔外所見；特記すべき事はなし。

口腔内所見; 舌下面正中部に弾性軟, 有茎性の直径 8 $\mathrm{mm}$ の腫瘤を認めた。同部には圧痛・自発痛ともになく， 表面粘膜も健常であり，可動性はなく周囲組織との境界は 明瞭であった（写真 1$)$.

初診時臨床診断：舌下面正中部良性腫瘍.

処 置: 平成 16 年 11 月 $\square$, 上診断のもと, 局所麻酔 下に切除生検術を行った。術中出血はほとんどなく, 通常 の舌良性腫痬切除の手順に準じて基底部の健常表面粘膜の 一部を腫瘤に付け一塊として切除を行い，これを病理組織 学的に精查した.

病理組織学的所見：異型の目立たない重層扁平上皮下 に，境界明瞭な結節状病变が認められる（写真 2). 異型の 目立たない成熟脂肪細胞のやや密な増生がみられ，その内 部では多結節状の軟骨組織が認められる（写真 $3 a ， b)$.

以上の病理組織学的所見より軟骨性分離腫 (cartilaginous choristoma）と診断した.

術後経過：術後 7 日目に抜系を行い, 以後経過観察をし ていたが, 術後 9 か月目の現在特に再発など異常は認めない.

考察

舌に発生する腫瘍は良性に限っても乳頭腫, 奇形腫, 脂 

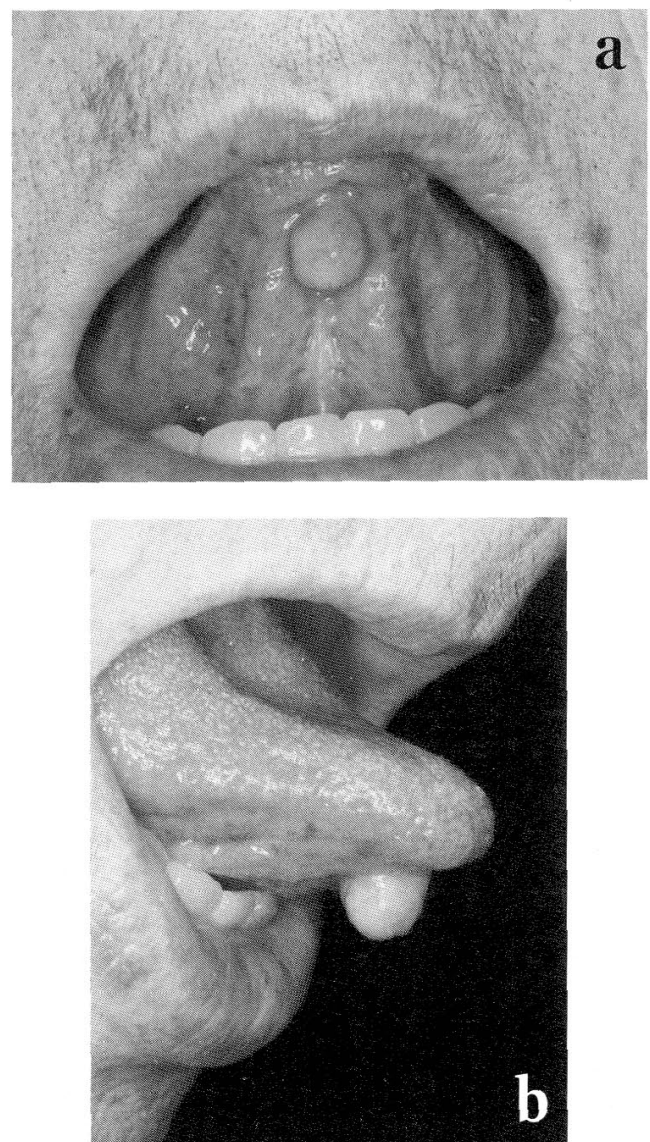

写真 1 初診時口腔内写真

a 正面観 b 側面観

舌下面正中に直径 $8 \mathrm{~mm}$ の弾性軟の腫瘤を認好た。
肪腫，血管腫など多岐にわたる。なかでも分離腄は比較的 まれな良性腫瘍である。軟骨分離腫は「個体発生の途中に おいて軟骨組織が正常な連続性を失って分離し別の組織内 に入り込んで生存増殖して腫瘤状を呈するもの」文と定義 されているが，「腫瘍としての自主性はあるが過剩な発育 はみられない22)といわ机ている。舌の骨性あるいは軟骨

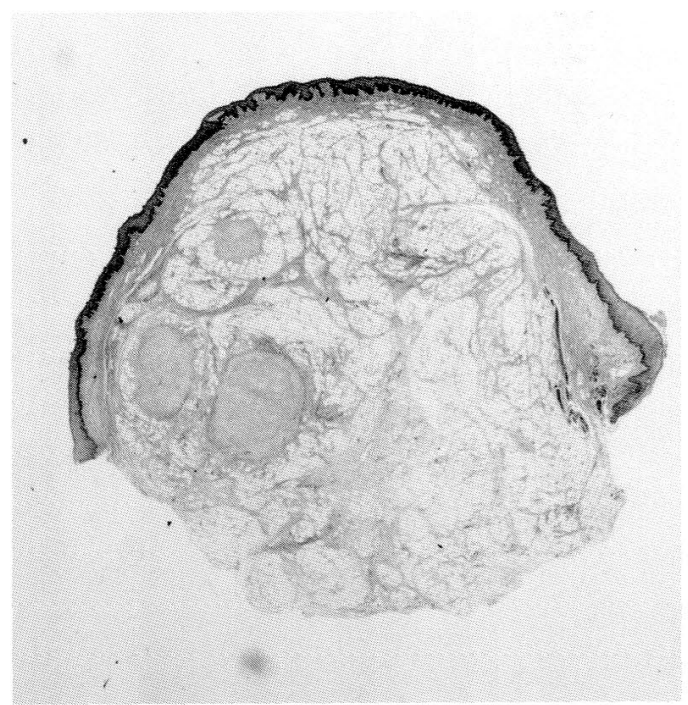

写真 2 病理組織像 $(H-E$ 染色，×1）

異型の日立たない重層扁平上皮下に境界明睹 な結節状病変がみられる。
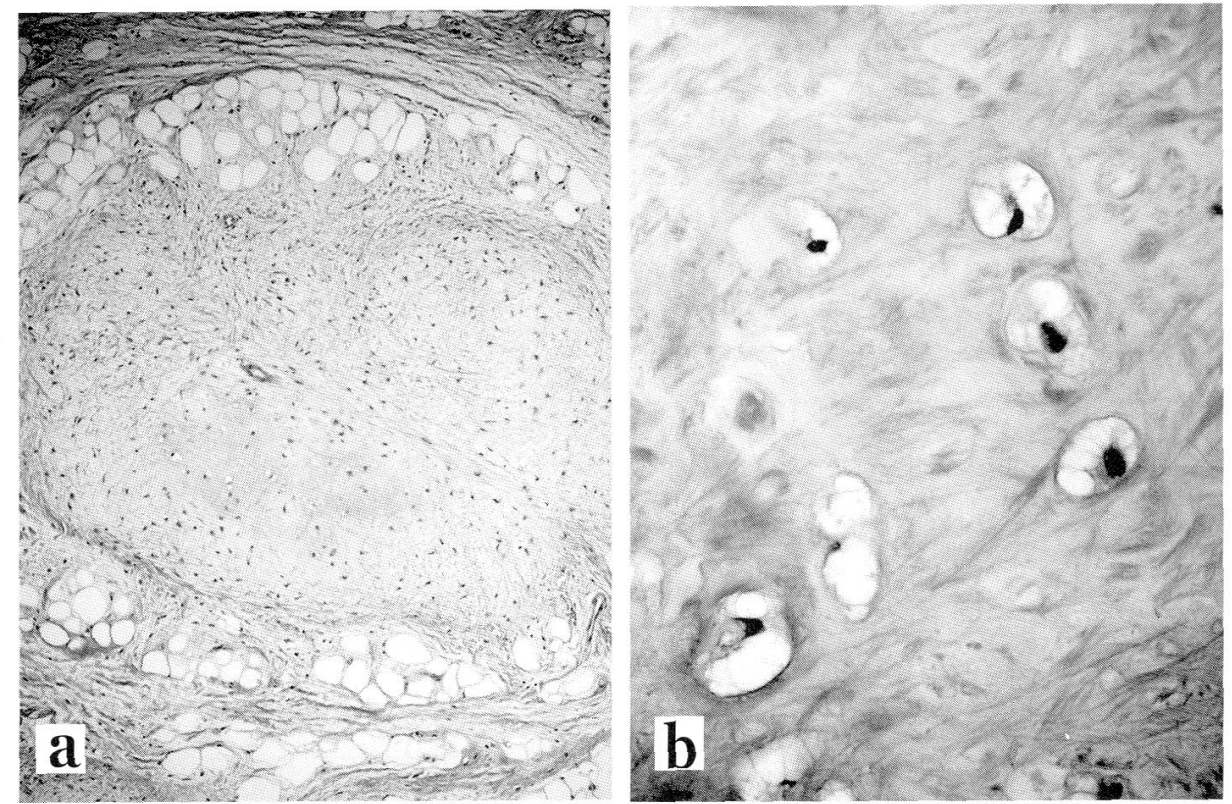

写真 3 病理組織像 (H-E 染色, $\mathrm{a} \times 10 \quad \mathrm{~b} \times 40)$

異型の日立たない成熟脂肪細胞のやや密な増生がみられ，その内部には多結節状の軟 骨組織が認められる。 
性分離腫は 1913 年の Mosarrat ${ }^{3)}$ の報告が最初とされ，本 邦では牟田ら ${ }^{4)}$ が 1938 年に舌盲孔部に発生した 1 例を報 告して以来 21 例が報告されているのみでまれな疾患とい える.X線検査に際し偶然発見されることが多く, 舌の側 方に存在する場合はパノラマX $\mathrm{X}$ 線写真でも明瞭に描出され ることがあるという。それゆえ部位によってはさまざまな 石灰化を伴う病変と詋診される. 発生部位としては煩粘膜 の報告もあるが，ほとんどは舌根部に発生し，なかでも盲 孔部が多い。本邦では舌分離腫の報告はわれわれが渉猟し 得た範囲ではこれまで 21 例（軟骨性 7 例，骨性 11 例，骨 性軟骨性混在 3 例）が報告されており，その内で軟骨性分 離腫は 10 例（舌背 5 例，舌腹 2 例，舌根 2 例，舌尖 1 例） あるが本症例と同じ部位の報告はない ${ }^{5)}$.

さまざまな疾患に伴って粘膜下や皮下に石灰化や骨化が みられる．副甲状腺ホルモン過剩症やビタミン D 過剩症， ミルクアルカリ症候群, アルブライト症候群など血中カル シウムや無機燐酸イオン濃度の増加を伴う疾患で石灰化の 起こることがある。而るいは翚皮症や皮膚筋炎, SLE，サル コイドーシスなど血中カルシウムや無機燐酸イオン濃度の 変動のない疾患にも石灰化は扔こる，皮膚には他にもさま ざまな角化性の新生物に伴い転移性の角化が抢こると報告 されている，しかし，舌に打ける軟骨性または骨性病変は 極めて珍しく，従来は軟骨腫（chondroma）または骨腫 （osteoma）などとよばれてきた，しかし本疾患は本来存在 すべき組織や器官と異なった部位に存在する原始細胞群か ら腫場状に増大したもので，分離腫と呼ばれる所以である。 軟骨性分離腫の発生に関しては，鰓弓由来，奇形線維腫の 化骨など諸説ある，文献的にはこの軟骨性分離腫の発生要 因として考光られているものは鰓弓の遺残 ${ }^{6)}$, 鰓弓の軟骨 芽の迷入 ${ }^{7)}$, 舌甲状腺化骨 ${ }^{8)}$ などさまざまである.しかし 真の発生原因は未だに不明である。本症例についても明ら
かな発生原因といえる既往はなかった.

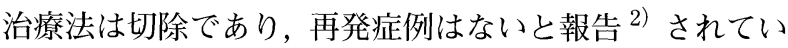


期間の経過観察が望ましいとされている．本症例について は術後 9 か月経過するが再発は認められない.

\section{結語}

舌下面正中部に発生したまれな軟骨性分離腫の一例を報 告した，切除後 9 か月経過するが再発もなく良好な経過を たどっている.

謝辞

病理組織学的検討にあたり大阪警察病院検査部長 辻本正 彦博士に多大な援助と尽力を頂いた。ここに深謝の意を表し たい。

\section{引用 文 献}

1）半田祐二郎：軟骨性分離腫. 内田安信, 河合 幹他 編集；䫈口腔外科診断治療体系．第 1 版，講談社， 東京, 1991, 355 頁.

2）高橋喜浩，河野憲司，他：舌背後方部に発生した骨 性分離腫の 1 例. 日口外誌 41: 428-429 1995.

3) Mosarrat, M.: Ostéome de langue. Bull Soc Anat 88: 282-283 1913.

4）牟田哲三郎，緒方 健：舌根部骨腫症例追加. 耳喉 11: 1016-1018 1938

5）古野 均, 梅野博仁, 他：舌に発生した軟骨性分離 腫. 耳鼻臨床 94: 155-158 2001.

6）五百藏一男，松本めぐみ：舌盲孔付近に発生した骨 性分離腫の 1 例. 日口外誌 32: 1057-1060 1984.

7）梅村 仁, 尾崎正義, 他：舌に生じた軟骨性打よび 骨性分離腫. 耳鼻臨床 83: 1403-1407 1990.

8) Mcclendon, E.H.: Lingual osseous choristoma. J Oral Surg 30: 39-44 1975. 